\title{
EGFR NP_005219.2:p.E746_T751del
}

National Cancer Institute

\section{Source}

National Cancer Institute. EGFR NP 005219.2:p.E746 T751del. NCI Thesaurus. Code C98547.

A deletion of six amino acids from the epidermal growth factor receptor protein from the glutamic acid at position 746 through the threonine at position 751. 